\title{
Termite-Repellent Activity and Chemical Composition of West Indian Mahogany Wood, (Swietenia Mahagoni Jaeq.) with Special Reference to the $P_{2}$ Fraction $^{1}$
}

\author{
Conrado F'. Asenjo, Luis Amorós Marin, Wanda Torres, and \\ Alice del Campillo ${ }^{2}$
}

\section{INTRODUCTION AND OBJECTIVE}

The studies of Wolcott $(1)^{3}$ on the resistance of different woods to the "polilla", as it is locally called, the West Indian dry-wood termite, Cryptotermes brevis Walker, confirmed what was already known through practical experience, i.e., that the West Indian mahogany (Swietenia mahagani Jacq.) is one of the few commercially available woods very resistant to this insect.

In 1951, one of us (C.F.A.) isolated (2) from West Indian mahogany wood a crude waxy-white substance which rated very high as a termite repellent when assayed by the biological method of Wolcott. This initial encouraging result, as well as the fact that a perusal of the literature revealed no investigations on the chemistry of West Indian mahogany wood, prompted this study.

\section{MATERIAL AND METHODS}

Three samples of West Indian mahogany were used. One sample was obtained from a local furniture shop, although it came originally from the Dominican Republic; it was used by Asenjo (2) and later by us. The other two samples were obtained in Haiti, through the courtesy of Ernst Wulff and Georges Deslandes of Port-au-Prince.

The first sample from the Dominican Republic was extracted, serially, with selective solvents, that is, first with petroleum ether (b.p. $30^{\circ}-60^{\circ} \mathrm{C}$.), and then, successively, with ethyl ether, acetone, 95-percent alcohol, water, 3-percent $\mathrm{HCl}$, and 2-percent $\mathrm{NaOH}$. The results of these extractions are

${ }^{1}$ A cooperative project with the Agricultural Experiment Station, University of Puerto Rico, Río Piedras, P. R.

2 Professor, Assistant Professor, Assistant, and Instructor, respectively, Department of Biochemistry and Nutrition, School of Medicine, School of Tropical Medieine, University of Puerto Rico, San Juan 22, P. R.

${ }^{3}$ Italic numbers in parentheses refer to Literature Cited p. 195. 
recorded in the following tabulation:

\section{Solvent}

Petroleum ether $\left(30^{\circ}-60^{\circ}\right.$ C. $)$

Ethyl ether

Acetone

Alcohol, 95 percent

Water

HCl, 3 percent

$\mathrm{NaOH}, 2$ percent, more than
Percentage extracted

0.73

.08

2.80

.30

2.10

.98

10.00

Each of the above extracts was assayed for termite-repellent activity by the Wolcott assay procedure $(3)^{4}$. This test consisted briefly of submerging a standard Flamboyan (Delonix regia) block, of about $0.7 \times 2 \times 3 \mathrm{~cm}$., for a period of 10 minutes in a solution of known concentration of the substance under test. After impregnation the blocks were dried in the sun and exposed in petri dishes to fresh live termites obtained from some infected piece of wood. Observations were made daily until the termites attacked the treated wood. The number of days after impregnation on which the block was attacked served as an index of repellency. By running this test using blocks impregnated with different concentrations of the substance assayed the minimum effective concentration could be determined.

The initial termite-repellent tests were carried out in the spring of 1951. The petroleum ether extract (PEE) was the only one of all those tested to exhibit promising termite-repellent activity.

\section{FRACTIONATION OF THE PETROLEUM ETHER EXTRACT}

After the petroleum ether was removed by distillation, a viscous reddishyellow oil remained, which deposited a waxy-white precipitate on standing at room temperature, but more at icebox temperature. This precipitate amounted to about 41 percent of the petroleum ether extractive and 0.3 percent of the original wood. The fractionation procedure used is indicated in the flow diagram on page 187.

Fractions $\mathrm{P}_{2 \mathrm{a}}, \mathrm{P}_{3}$, and $\mathrm{P}_{4}$ had the same softening range and the same solubility as $\mathrm{P}_{2}$. Also, all these fractions reacted with hot diluted aqueous $\mathrm{NaOH}$, turning deep brown in color and developing an elusive aromatic odor. After saponification a waxlike residue with solubility properties similar to the original material (fraction $P_{5}$ ) was left. It was purified by reprecipitation from alcohol after being decolorized with charcoal (Darco). The softening range of this amorphous material was lower $\left(90-96^{\circ} \mathrm{C}\right.$.) than that of the original fraction (see table 1).

${ }^{4}$ All termite-repellent.assays reported in this paper were performed by George N. Wolcott, Entomologist, Agricultural Experiment Station, Río Piedras, P. R. Our sincere thanks to Dr. Wolcott who is now retired. 
TERMITE-REPELLENT ACTIVITY IN WEST INDIAN MAHOGANY 187

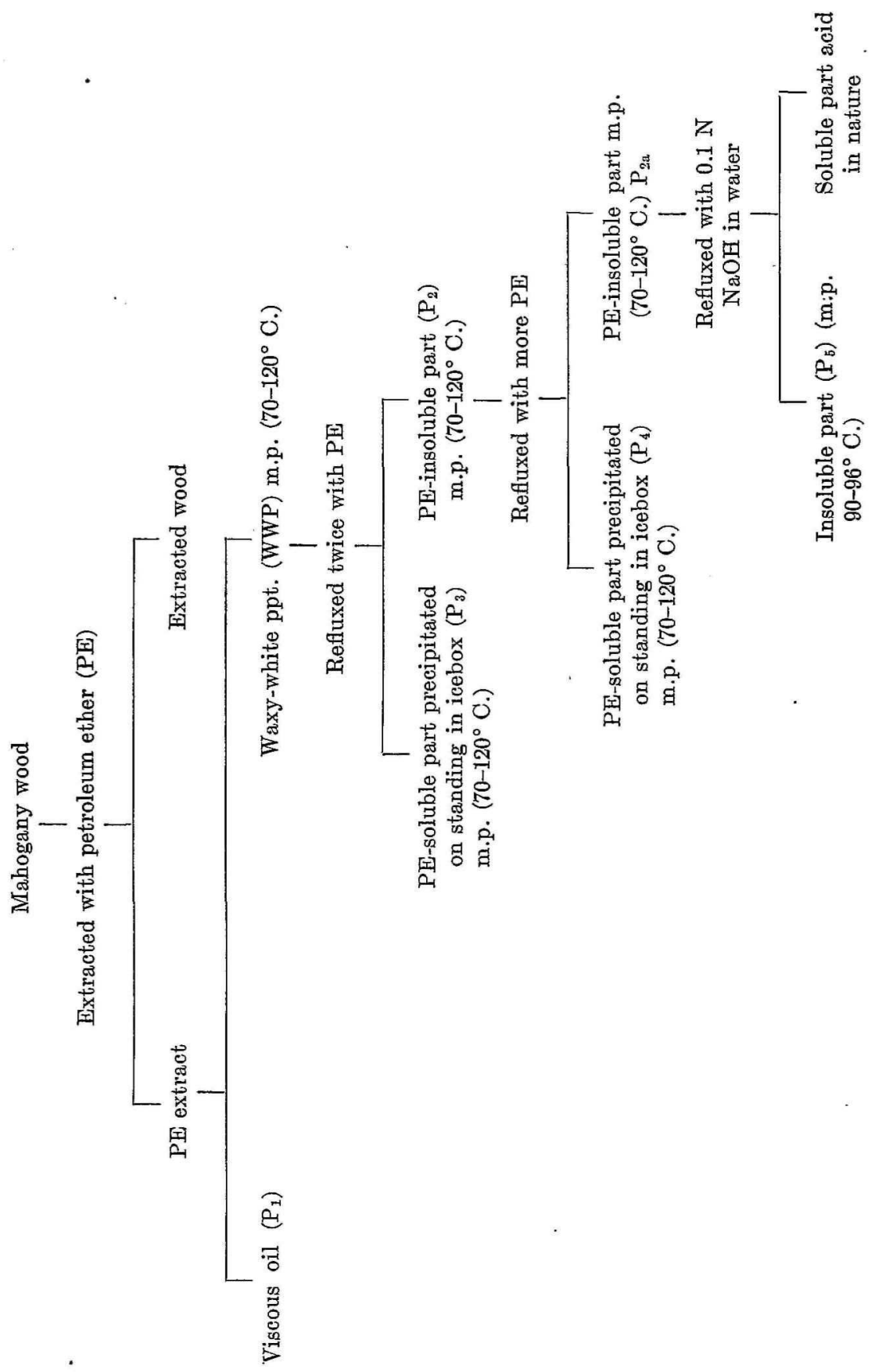


Acidification of the alkaline liquor with $\mathrm{HCl}$ yielded a sticky, somewhat oily brown substance that floated in the aqueous medium and which was removed with petroleum ether in which it was soluble. Attempts to purify this acidic fraction and/or to prepare derivatives from it were unsuccessful.

\section{RESULTS}

TERMITE-REPELLENT ACTIVITY

In table 2 are tabulated the termite-repellent activites of the different fractions separated. Fractions $\mathrm{P}_{2}$ and $\mathrm{P}_{3}$, the first one in particular, ex-

TABLE 1.-Termite-repellent activity by Wolcott assay procedure of fractions from the petroleum ether extract of West Indian Mahogany wood

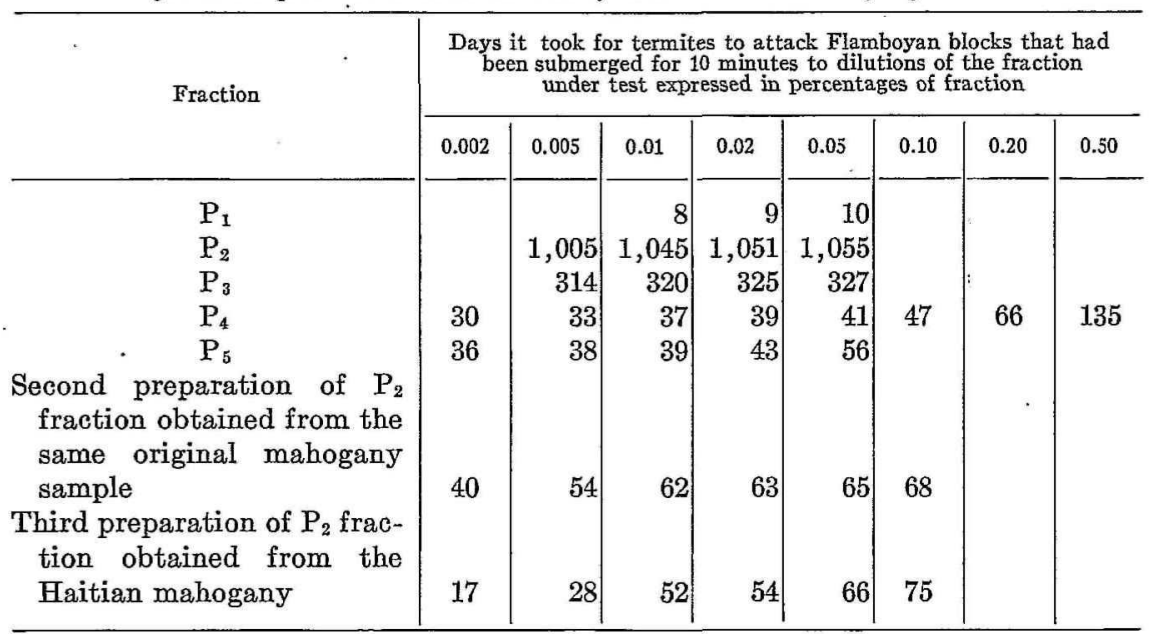

hibited a high repellent activity, protecting Flamboyan blocks for over 1,000 days at a concentration of only 0.005 percent. However, other $\mathrm{P}_{2}$ fractions prepared at later dates by the same procedure, exhibited much lower termite-repellent activity.

Another approach used to determine the effect of petroleum ether on the termite-repellent activity of mahogany was to exhaustively extract standard assay blocks of mahogany with petroleum ether for several days. When these blocks were exposed to live termites, they were attacked, thus indicating that extraction with petroleum ether in some way made mahogany wood susceptible to termite attack (fig. 1) ${ }^{5}$.

${ }^{5}$ The original test was carried out by Dr. Wolcott. We repeated it and obtained similar results. Fig. 1 is a photograph of the test carried out by us. 


\section{SOLUBILITY CURVE OF THE P2 FRACTION}

The solubility of the $\mathrm{P}_{2}$ fraction in double-distilled petroleum ether (b.p. $30-60^{\circ}$ C.) at $28^{\circ}$ C. was of about $0.16 \mathrm{gm}$. per $100 \mathrm{ml}$. of solvent. Its solubility in normal heptane was of about the same order of magnitude as in petroleum ether.

In order to determine whether the $P_{2}$ fraction was composed of only one

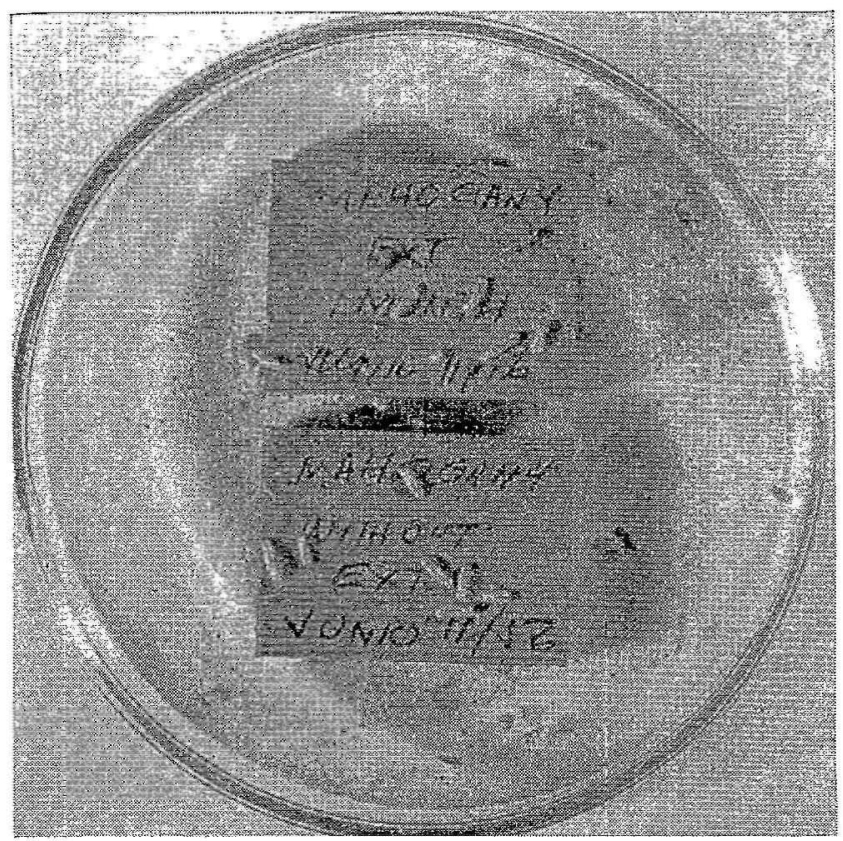

FIG. 1.-Mahogany blocks exposed to live termites. Upper block was extracted during 1 month with petroleum ether. Lower block was not extracted. The boring action of termites on the surface of the upper block is evident, especially the hole near the left-hand edge.

solid phase (a pure chemical compound) or of more than one solid phase (a mixture) the method of analysis of solubility curves described by Kunitz and Northrop (4) was used. This method consists briefly in determining the fraction of substance under investigation that will go into solution when increasing amounts of the solid substance are put in contact with an equal volume of the solvent used.

The above analysis applies only to mixtures which give curves having sharp breaks. When a curve with only one sharp break is obtained, it indicates that the substance under investigation is a pure homogeneous substance having, of course, only one solid phase. Additional sharp breaks 
indicate more than one solid phase present in the substance. A smooth curve indicates a solid solution and cannot be analyzed by this method.

The solubility curve constructed using the $\mathrm{P}_{2}$ fraction as solute and normal heptane as solvent (fig. 2) indicated that the $P_{2}$ fraction is probably a mixture of two major components and an additional minor one, thus indicating that the $\mathrm{P}_{2}$ fraction is not a homogeneous substance.

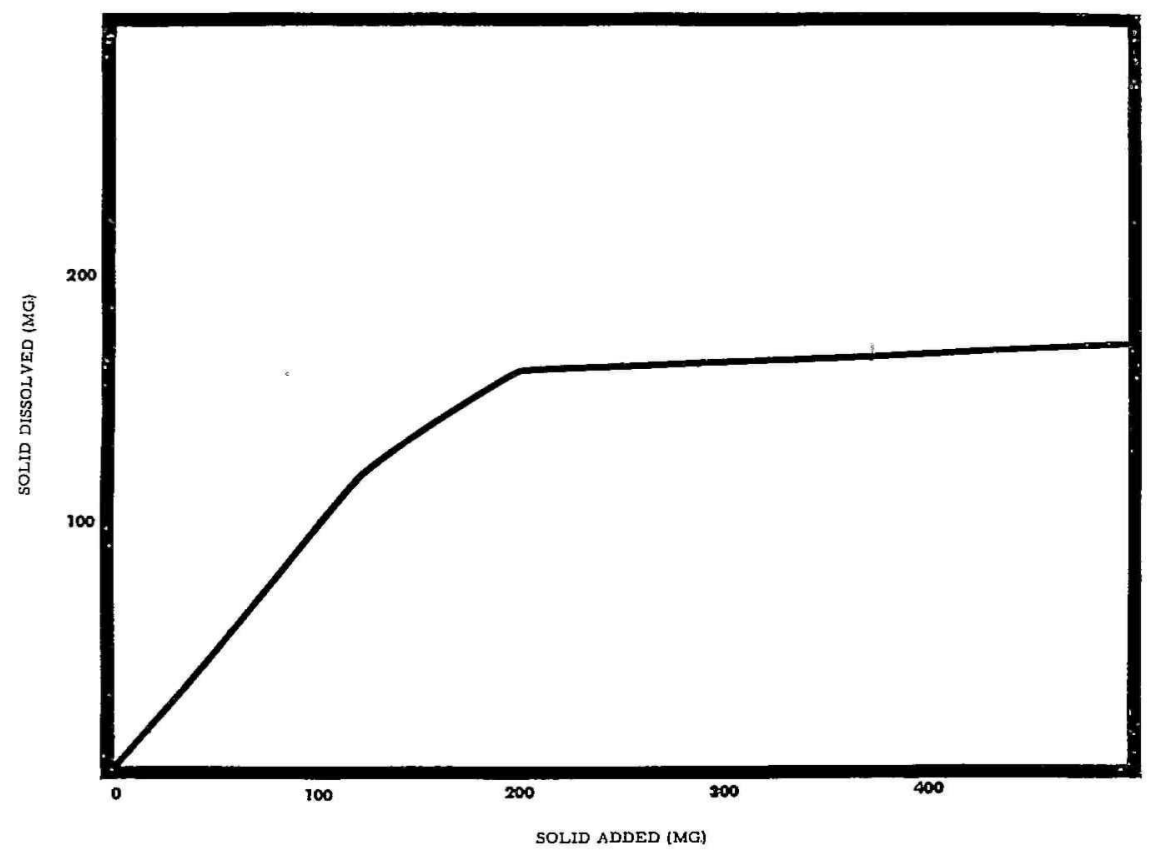

FIG. 2.- Solubility curve of the $P_{2}$ fraction in normal heptane.

PHYSICAL AND CHEMICAL CHARACTERISTICS OF THE $\mathrm{P}_{2}$ FRACTION

Some of the principal physical and chemical characteristics of the $P_{2}$ fraction are reported in tables 2 and 3.

$\mathrm{P}_{2}$ is highly soluble in all organic solvents except low molecular-weight hydrocarbons. It is slightly soluble with decomposition in dilute strong alkaline solutions and soluble without apparent decomposition in concentrated $\mathrm{H}_{2} \mathrm{SO}_{4}$ and $\mathrm{H}_{3} \mathrm{PO}_{4}$.

Tests made for halogens, nitrogen, and sulfur gave negative results. As the substance burns readily without leaving any ash, it was assumed to contain $\mathrm{C}, \mathrm{H}$, and $\mathrm{O}$ only. It has a negative rotation of about $21^{\circ}$ and the iodine number indicates the presence of at least one unsaturated bond. 
TABLE 2.-Solubility of the $P_{2}$ fraction at $28^{\circ} \mathrm{C}$.

\begin{tabular}{|c|c|c|c|c|}
\hline Insoluble in- & $\underset{\text { Very slightly soluble }}{\text { in- }}$ & $\begin{array}{l}\text { Slightly sol- } \\
\text { uble in- }\end{array}$ & Soluble in- & Very soluble in- \\
\hline $\mathrm{H}_{2} \mathrm{O}$ & $\begin{array}{l}\text { Petroleum ether } \\
\left(30^{\circ}-60^{\circ} \text { C. }\right)\end{array}$ & $\begin{array}{l}\mathrm{NaOH} \\
\text { (dilute) }\end{array}$ & $\begin{array}{l}\mathrm{H}_{2} \mathrm{SO}_{4} \text { (concen- } \\
\text { trated) }\end{array}$ & Diethyl ether \\
\hline HCl (dilute) & Normal-heptane & & $\begin{array}{l}\mathrm{H}_{3} \mathrm{PO}_{4} \text { (concen- } \\
\text { trated) }\end{array}$ & Acetone \\
\hline $\begin{array}{l}\mathrm{NaHHCO}_{3} \text { (di- } \\
\text { lute) }\end{array}$ & & & ' & $\begin{array}{l}\text { Dioxane } \\
\text { Cyclohexane } \\
\text { Chloroform } \\
\text { Benzene } \\
\text { Ethyl alcohol } \\
\text { Carbon disulfide }\end{array}$ \\
\hline
\end{tabular}

TABLE 3.-Some physical and chemical characteristics of the $P_{2}$ fraction from the extract of West Indian Mahogany wood

\begin{tabular}{|c|c|c|}
\hline Physical and chemical characteristics & Values found & Remariks \\
\hline Melting range (capillary tube) & $70-120^{\circ} \mathrm{C}$. & Hot stage gave similar re- \\
\hline Average molecular weight: & & sults \\
\hline a. Rast & 550 & Using eamphor \\
\hline b. Lowering of the freezing point & 500 & Using benzene as solvent \\
\hline e. Raising of the boiling point & 800 & Using benzene as solvent \\
\hline $\begin{array}{l}\text { d. Calculated from iodine number } \\
\text { assuming one double bond }\end{array}$ & 652 & \\
\hline e. Calculated from saponification & 540 & \\
\hline $\begin{array}{l}\text { number assuming one carboxyl } \\
\text { group }\end{array}$ & & \\
\hline$[\alpha]_{D}^{27^{\circ} \mathrm{C} . \text { in chloroform }}$ & -21.2 & \\
\hline Elements present: & C, H, O only & Range of 13 analyses \\
\hline Percent $\mathrm{C}$ & 60.67 & $(59.25-61.56)$ \\
\hline Percent H & 6.71 & $(6.36-6.91)$ \\
\hline Percent $O$ (by difference) & 32.62 & $(31.53-34.06)$ \\
\hline Methoxyl content & 11 percent & \\
\hline Iodine value & 38.9 & Hanus method \\
\hline Saponification value & 105.0 & Using alcoholic $\mathrm{KOH}$ \\
\hline Percentage of unsaponifiable & 12 & Using alcoholic $\mathrm{KOH}$ \\
\hline Active hydrogen & 0.17 percent & \\
\hline$\left(\mathrm{CH}_{3}\right)-\mathrm{C}$ & 11.75 percent & \\
\hline
\end{tabular}

\section{ALKALINE HYDROXAMIC REACTION}

The $\mathrm{P}_{2}$ fraction gave a positive hydroxamic reaction under alkaline conditions, a reaction typical of esters. On the other hand, the possibility of the presence of acid anhydrides was ruled out when the reaction mixture was incubated at a neutral pH (5) and no reaction took place. A modifica- 
tion of chromatographic detection of acyl phosphates of Stadtman and Barker (6), based on the formation of hydroxamic acids and extraction and concentration of the same with alcohol and subsequent separation by paper chromatography, using water-saturated butanol as solvent, was used. A series of paper chromatograms consistently showed four definite spots as follows: One faint spot between $R_{\mathrm{f}} 26-31$; a second spot 51-53; a third 6970; and a fourth faint spot at 85-88. As the first and fourth spots were visible before spraying with $\mathrm{FeCl}_{3}$, they were probably due to some nonspecific reaction or impurity. Chromatograms were run using both Whatman No. 1 and No. 3 paper obtaining identical results. Spots No. 2 (Rf 51-53) and No. $3\left(R_{\mathrm{f}} 69-70\right)$ seemed to be due to true acids, as they developed only after spraying with $\mathrm{FeCl}_{3}$. In the literature $(6)$ the $\mathrm{R}_{\mathrm{f}}$ for acetic and propionic acids are 52 and 65 , respectively. Under our conditions known samples of acetic and propionic acids gave $R_{\mathrm{f}}$ values of 49 and 70 , respectively, therefore, seems that acetic and propionic acids are present in the form of esters in the $P_{2}$ fraction.

\section{ATTEMPTS TO PREPARE CRYSTALIINE ADDUCTS OF UREA AND THIOUREA}

Urea forms crystalline complexes with almost any type of straight chain organic molecule, while thiourea acts in the same way in the presence of eyclic compounds ( 7$)$.

No complexes were obtained when the $\mathrm{P}_{2}$ fraction dissolved in methanol was mixed with urea or thiourea dissolved in the same solvent. Controls run at the same time with oleic acid and cyclohexane in methyl alcohol as solvent, yielded beautiful crystalline complexes with urea and thiourea, respectively.

\section{ULTRAVIOLET SPECTRUM}

The ultraviolet absorption curve (Beckmain DU spectrophotometer) of $\rightarrow$ the $\mathrm{P}_{2}$ fraction in ethanol $(0.13 \mathrm{mg}$./ml. $)$ showed a maximum at 217 and shoulders at 270 and 288 . In cyclohexane the maximum was at 221 with shoulders also at 270 and 288.

The ultraviolet absorption curve of the $P_{2}$ fraction was not a very specific one and, therefore, did not aid greatly in characterizing the compounds present in this mixture.

\section{INFRARED SPECTRUM ${ }^{6}$}

The infrared spectrum of the $\mathrm{P}_{2}$ fraction was determined for us at the Eastern Utilization, Branch of the Department of Agriculture in Phil-

${ }^{6}$ We are indebted to Dr. Thomas D. Fontaine, and Mr. J. S. Ard, Biologically Active Chemical Compounds Section, Agricultural Research Service, USDA, Philadelphia, Pa., for the infrared analysis. 
adelphia. The most important facts suggested by the infrared spectrum of the $\mathrm{P}_{2}$ fraction were the following:

1. Presumably an $\mathrm{OH}$ group is present which chelates intramolecularly. This is in accordance with the fact that the $\mathrm{P}_{2}$ fraction is resistant to acetylation and that it has an active hydrogen as already indicated. However, it should be considered also that carbonyl over tones may cause a false interpretation of hydroxyls.

2. The compounds should be essentially aliphatic in nature.

3. There are indications of a carbonyl group, but one that is different from those in simple ketones or esters, and more like one in a tight environment like a pentacyclic ring having an unsaturated bond.

4. There are indications of one or more unsaturated bonds present. This is in agreement with the iodine number which indicates at least one double bond in one of the molecules.

5. There are indications of a possible $\mathrm{Cis} \mathrm{RCH}=\mathrm{CHR}$ group.

6. The presence of $\mathrm{CH}_{2}$ groups like in a normal chain is also evident from the curve.

7. The presence of $\left(\mathrm{CH}_{3}\right)-\mathrm{CH}$ is indicated.' This was confirmed by actual analysis.

8. Possible presence of an ether group. This was confirmed by analysis.

9. A strong band at $1,227 \mathrm{~cm}^{-1}$ usually is dependable evidence of an ester group although the carbonyl band location at $1750 \mathrm{~cm} .^{-1}$ is significantly different from that of noncyclic esters.

10. The general character of the infrared curve is negative for aromatic rings, anhydrides, and acetylenic groups. Also it suggests $\mathrm{COOH}$ and $\mathrm{CHO}$ radicals to be absent.

\section{DISCUSSION}

The termite-repellent activity of mahogany wood seems to be present in a compound that is either extracted by petroleum ether from the wood or that, in some way, is inactivated in situ by this solvent. A solid waxy substance $\left(\mathrm{P}_{2}\right.$ fraction) isolated from the petroleum ether extractive, exhibited, at times, high termite-repellent activity, although large variations in repellent activity were observed from batch to batch.

From the available evidence, it seems that the different $P_{2}$ fractions studied contained variable quantities of a termite-repellent principle. The variable repellent activity exhibited by different $P_{2}$ preparations may be explained by the hypothesis that the termite-repellent principle is a very labile compound that suffers different degrees of chemical modifications during the isolation procedure.

A simple experiment that has offered substantial evidence to the effect that petroleum ether either removes the termite-repellent principle from 
mahogany wood or, in some way, inactivates the same in situ, was the one in which mahogany blocks were subjected to exhaustive extraction with petroleum ether. The surface of these blocks became susceptible to termite attack.

The $\mathrm{P}_{2}$ fraction, according to all the available evidence, is a mixture. The shape of the solubility curve in normal heptane suggested the presence of two major components, in addition to a minor one. The $\mathrm{P}_{2}$ fraction contained only carbon, hydrogen, and oxygen, and its average percentage elemental composition from different samples of mahogany wood was very similar. The same is true in regard to the average molecular weight when determined by any one of the specific methods indicated.

As the $\mathrm{P}_{2}$ fraction reacts with strong alkalies with decomposition and with the formation, at times, of a volatile substance of agreeable aromatic odor, the possibility of the presence of esters in this mixture has been highly suspected. This conclusion as to the chemical nature of the $\mathrm{P}_{2}$ fraction receives further support from the interpretation of the infrared spectra and the hydroxamic acid reaction, both of which strongly point to the presence of esters in this fraction.

\section{SUMMARY}

1. Serial extraction of West Indian mahogany wood with selective solvents was performed.

2. The petroleum ether extract was the only fraction to exhibit promising termite-repellent activity.

3. Mahogany blocks subjected to petroleum ether extraction became susceptible to termite attack.

4. A waxy substance ( $\mathrm{P}_{2}$ fraction) separated from the petroleum ether extract at times showed high termite-repellent activity. The termiterepellent principle in the $\mathrm{P}_{2}$ fraction seems to be a labile one, as the termiterepellent activity varied greatly from batch to batch.

5. The $\mathrm{P}_{2}$ fraction is a mixture of two major components and of at least a third minor one. As far as we have been able to determine this mixture, at the elemental level, contains carbon, hydrogen, and oxygen only, while esters have been the only compounds definitely characterized at the structural level.

\section{RESUMEN}

1. Se llevó a. cabo una extracción en serie de la madera de caoba con solventes selectivos.

2. El extracto de éter de petróleo demonstró la mayoractividad en cuanto a su acción repelente a la polilla.

3. Bloques de madera de caoba extraídos con éter de petróleo se tornaron susceptibles a los ataques de la polilla. 
4. Una substancia cerosa (fracción $\mathrm{P}_{2}$ ) separada del extracto de éter de petróleo demostró a veces una gran actividad repelente a la polilla. El principio repelente a la polilla de la fracción $\mathrm{P}_{2}$ parece ser inestable, ya que su actividad repelente varió mucho de una prueba a otra.

5. La fracción $P_{2}$ parece ser una mezcla de dos componentes en mayor y untercero en menor cantidad. Hasta lo que hemos podido determinar esta mezcla, al nivel elemental, contiene solamente carbono, hidrógeno y oxígeno, mientras que al nivel estructural ésteres solamente han sido identificados.

\section{LITERATURE CITED}

1. Wolcott, G. N., An index to the termite-resistance of woods, Bul. 58, Univ. P. R., Agr. Exp. Sta., Sept. 1950.

2. Asenjo, C. F., Aislamiento de una fracción con actividad repelente a la polilla de la caoba antillana, Bol. Coleg. Quim. de P. R. 11, 5-6, 1954.

3. Wolcott, G. N., Termite repellents: A summary of laboratory tests, Bul. 73, Univ. P. R., Agr. Exp. Sta., Aug. 1947.

4. Kunitz, M., and Northrop, J. H., Solubility curves of pure proteins and of mixtures and solid solutions of proteins, Cold Spring Harbor Symposia, 6 325-30, 1938.

5. Hestrin, S., The reaction of acetylcholine and other carboxylic acid derivatives with hydroxylamine, and its analytical application, J. Biol. Chem. 180 249-61, 1949.

6. Stadtman, E. R., and Barker, H. A., Fatty acid synthesis by enzyme preparations of Closiridium Kluyveri; VI: Reactions of acyl phosphates, $J$. Biol. Chem. 184 769-93, 1950.

7. Fergunson, L. N., Molecular association of organic substances, J. Chem. Educ. $31626-30,1954$. 